\title{
Water Quality in Watershed of the Jaboatão River (Pernambuco, Brazil): a Case Study
}

\author{
Antonio Donizetti Gonçalves de Souza* and José Galizia Tundisi \\ Programa Pós-Graduação Ecologia e Recursos Naturais; UFSCar; Via Washington Luiz, km 235; 13565-905; \\ São Carlos - SP - Brazil
}

\begin{abstract}
The purpose of the present work was to evaluate anthropogenic influences on the water quality and to offer a subsidy to the establishment of water quality goals in the Jaboatão River Basin (Pernambuco State, Brazil). Eight sampling points were established and were sampled monthly during one hydrological cycle (March/98February/99). The following variables were analyzed: temperature, $\mathrm{pH}$, conductivity, chlorine, alkalinity, dissolved oxygen, biochemical oxygen demand, fecal coliforms, nitrate, total phosphorus and total solids. The most critical variables related to water quality objectives were dissolved oxygen, fecal coliforms and total phosphorus. Maps of land use, legally protected areas, area industries, and water withdrawals were utilized in order to propose division of the watershed into regions and to provide water quality management information.
\end{abstract}

Key words: Watershed; Water quality; Environmental management

\section{INTRODUCTION}

Human society utilizes water for purposes such as domestic, irrigation, navigation, assimilation of residues, etc. These uses cause conflicts that require effective water management, for which several instruments exist that aid in the rational use of water resources in the watersheds. In this context, the classification of water bodies according to uses is a powerful tool in water quality management. The classification systems of water bodies are usually established according to legal standards. Subsequently, in each watershed, the reaches of the rivers are classified accordingly. Seager (1993) stated that this provided a firm basis for protecting water quality and to provide improvements where required. Barth (1999) affirmed that water quality classification of rivers should be seen as a goal to be reached over time.
One of the fundamental guidelines for implementing this instrument is that it should not be based on the current state of the water body, but on the quality levels necessary to meet needs. This concept reinforces the classification should be within a context of wide watershed planning. In Brazil, the classification of the water bodies according to uses was established by resolution $\mathrm{n}^{\circ} 20$ of (CONAMA) Conselho Nacional do Meio Ambiente on 06/18/1986 and in several Brazilian states it has served as standard in monitoring and controlling water pollution. According to it, waters were classified as fresh water (special, 1, 2, 3 and 4 classes); brackish waters (classes 7 and 8), and saline waters (classes 5 and 6). For each class, conditions and standards limits of several water quality variables were also established (Brasil, 1986). 
Water body classification by use is also one of the instruments provided for in federal law $\mathrm{n}^{\circ}$. 9433/97, which defined the National Water Resources Policy for Brazil and created the National Water Resources Management System (Brasil, 1997). Water quality evaluations and comparisons with legal classification norms are crucial for identifying the critical locations and providing subsidies for decision making, and thus facilitating selection of priorities in adopting corrective measures. The purpose of the present work was to evaluate anthropogenic influences on water quality and to offer a subsidy in the establishment of water quality goals in the Jaboatão watershed (Pernambuco State, Brazil).

\section{STUDY AREA}

The Jaboatão watershed, located in Northeastern Brazil, in Pernambuco State $\left(8^{\circ} 00^{\prime}-8^{\circ} 14^{\prime} \mathrm{S}\right.$ and $34^{\circ} 50^{\prime}-35^{\circ} 15^{\prime} \mathrm{W}$ ), is $413 \mathrm{~km}^{2}$ in area and $75 \mathrm{~km}$ in length. The river crosses the Metropolitan Region of Recife (MRR), the mouth is on the Atlantic Ocean. (Fig. 1). The annual mean temperature is approximately $24^{\circ} \mathrm{C}$. Annual rainfall varies from $2000 \mathrm{~mm}$ in the littoral region to $700 \mathrm{~mm}$ in the upper basin (CPRH, 1995). The regional year can be divided in two different periods: the winter season, with frequent rain (March to August) and the summer season, with lower amounts of rain (September to February). The specific and decenal flows are $3.40 \mathrm{~L} / \mathrm{s} . \mathrm{km}^{2}$ and $2034.00 \mathrm{~L} / \mathrm{s}$ respectively (Acquaplan 1990).

The watershed drains six municipalities: Vitória de Santo Antão, Cabo de Santo Agostinho, Moreno, São Lourenço da Mata, Jaboatão dos Guararapes, and Recife. The main sources of pollution are a mill, usina Bulhões that in summer discharges effluents into the river, and Portela, a paper and cellulose manufactures, both located in Jaboatão dos Guararapes. In addition, untreated sewage also impacts water quality. The Jaboatão River is not yet classified according to CONAMA resolution 20/86.

\section{MATERIALS AND METHODS}

Based on anthropogenic influences, eight sampling points were established in the watershed (Fig. 1) at sites comprising part of the water quality monitoring program of the Companhia Pernambucana do Meio Ambiente (CPRH). Sites JB-10 and JB-22 were situated in an intensely urban area; JB-15 and JB-20 in upstream and downstream the Usina Bulhões; JB-35 in the mouth of the Duas Unas River, downstream from the industrial area; JB-41 located downstream Portela; JB-55 and JB-75 in a region distant from the direct impacts near the river mouth. Water sampling frequency was monthly from March/98 to February/99. The following variables were analyzed (APHA, 1995): temperature $\left({ }^{\circ} \mathrm{C}\right), \mathrm{pH}$, conductivity $(\mu \mathrm{S} / \mathrm{cm})$, alkalinity $(\mathrm{mg} / \mathrm{L})$, chlorine $(\mathrm{mg} / \mathrm{L})$, dissolved oxygen $(\mathrm{mg} / \mathrm{L})$, biochemical oxygen demand (BOD) (mg/L), fecal coliforms (NMP/100ml), nitrate $(\mu \mathrm{g} / \mathrm{L})$, total phosphorus $(\mu \mathrm{g} / \mathrm{L})$, and total solids $(\mathrm{mg} / \mathrm{L})$. Exploratory data analysis was performed by factor analysis and median values obtained in the winter and summer periods were utilized. Factor extraction was obtained by principal component analysis. Thematic maps of land uses and legal protection areas were made based on documents produced by FIDEM - Fundação de Desenvolvimento da Região Metropolitana do Recife (FIDEM, 1987a, 1987b, 1987c, 1995). AutoCAD and SIG-IDRISI software was utilized for digitizing and editing the maps. Water withdrawals and the main polluting industries were located by Global Positioning System (GPS). Based on maps of the legal protection areas, water withdrawals and industries, regions with water uses restrictions were delimited. Within these regions groups of water bodies were established using guidelines for protection and recovery and proposing water quality classes based on CONAMA resolution 20/86. 


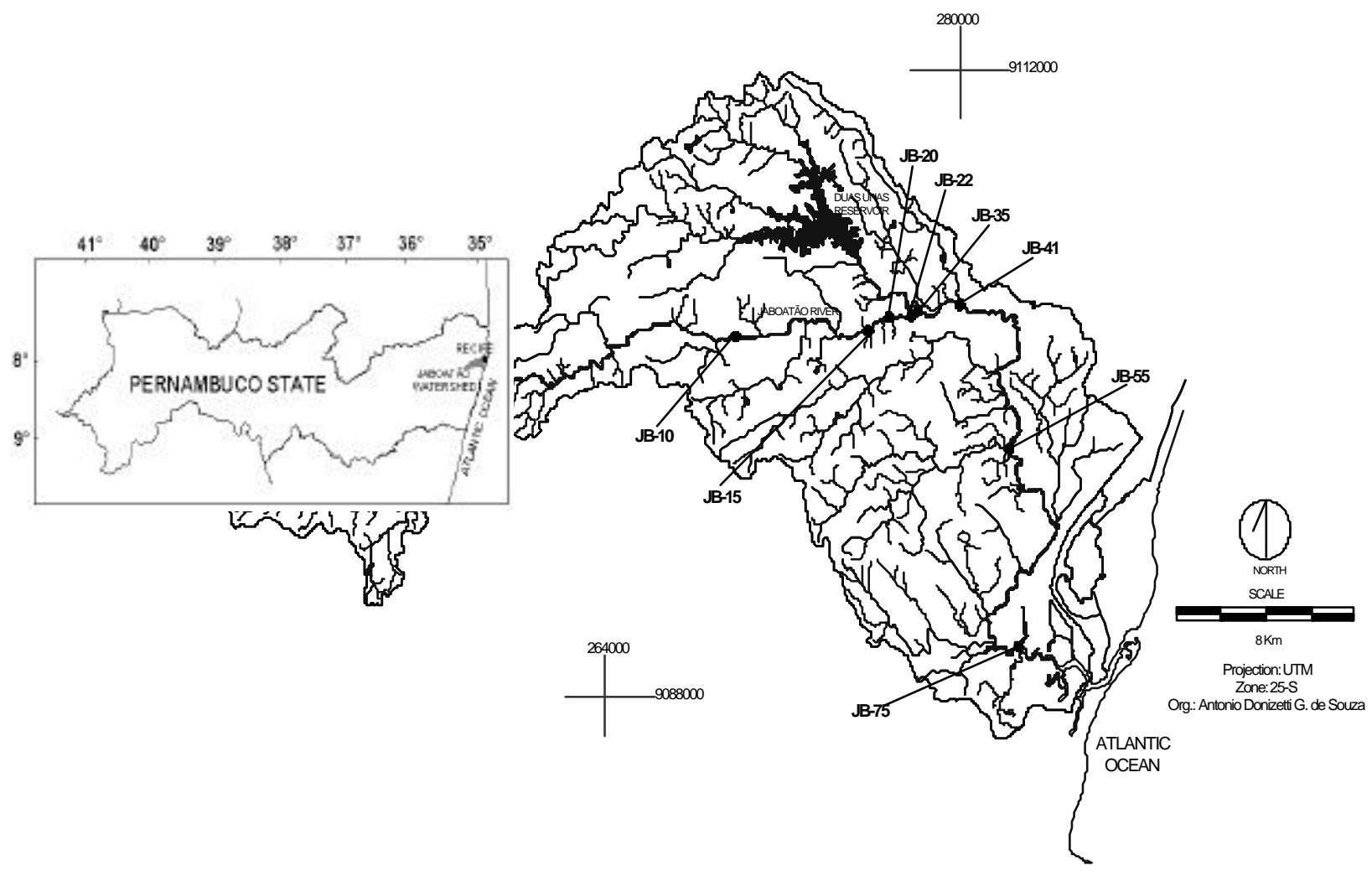

Figure 1 - Location of sampling sites along the Jaboatão watershed.

\section{RESULTS AND DISCUSSION}

According to Peters and Meybeck (2000), water quality mirrors the combined effect of many processes occurring along its banks. In developing country metropolitan regions, spatial disorganization in particular worsens river contamination (Pegram, 1999). These problems were found in MRR in the area of the Jaboatão River basin, and indicated the need of an integrated approach for the watershed planning and decision making relating to its environmental recovery.

Figure 2 shows land use in the watershed, mainly sugarcane, with $58.31 \%$ of the total area and the few remaining forests $(0.57 \%)$. In Figure 3, legal protection areas and present and future water withdrawals appear. Most industries are located in the littoral region, in the town of in Jaboatão dos Guararapes (Fig. 4).

The results of water quality analyses are showed in Table 1. In general, during the summer, median values were more elevated for variables related to ionic content of the water (conductivity, alkalinity, chlorine, and total solids). This could be explained by the higher ion concentration in the water in this period; in winter, the inverse phenomenon occurred, with dilution of these elements due to rain. Maier (1977) reported this same occurrence for the Mogi-Guaçu River.

Spatially, except for the JB-75 site located at the estuary of the river, stations JB-35 and JB-41 registered the highest values for the conductivity, alkalinity, and chlorine. The spatial distribution of dissolved oxygen showed an anoxic state in practically the entire reach studied. The median values registered varied from $0.00 \mathrm{mg} / \mathrm{L}$ to 3.80 $\mathrm{mg} / \mathrm{L}$. The BOD values showed an inverse relation with oxygen; the highest median values were registered at sites JB-41 and JB-20 (135.40 mg/L and $134.95 \mathrm{mg} / \mathrm{L}$, respectively).

Most sampling sites showed maximum values for fecal coliforms (1600000 NMP/100 ml). The highest median values were found at stations located in urban areas: JB-10, JB-20, JB-22, JB35 , and JB-41. Sites JB-55 and JB-75 showed lower median values during the study period. The results indicated anthropogenic influences in practically all the samplings points monitored. 
The impacts caused by usina Bulhões were detected at station JB-20, which showed elevated values for temperature, BOD, total phosphorus, and nitrate, and low levels of oxygen during the period of its operation (summer). In addition, the water withdrawals in this period for use in processing sugarcane caused a dilution capacity decrease of the river. The elevated values of $\mathrm{pH}$, conductivity, alkalinity, and total solids at site JB35 indicated the influence of the industrial area upstream. Dimitrova et al. (1998) reported $\mathrm{pH}$ peaks at sampling points situated in downstream industrial areas. Prat and Munné (2000) registered a longitudinal conductivity gradient caused by urban and industrial water uses along the drainage area of lotic environments. At site JB-41, the higher median alkalinity values in summer probably indicated discharges from Portela. According to Leitão (1999) and Guaglianoni (1998), this type of industry produced effluents with high concentrations of chlorine and $\mathrm{NaOH}$, used in removal of lignin from wood in the paper production process.

Fecal contamination was more evident at sampling points located near urban areas, which showed a spatial decrease gradient towards the mouth of the river in the estuary. This was also found by Mallin et al. (2000). According to these authors, headwater stations were more influenced by pollution due to their location near urban areas; on the other hand, estuarine sites reflected the dilution process and also salinity. Several studies have demonstrated that fecal coliforms survival decreased in waters of high salinity (Hanes and Fragala, 1967; Evison, 1988).

Factor analyses are represented in Table 2 and Figure 5. For winter, two factors explained $68.61 \%$ of the variance. Factor 1 presented high positive correlation of the following variables: $\mathrm{pH}$, alkalinity, conductivity, total phosphorus, and total solids. Factor 2 indicated fecal coliforms with negative correlation. Figure 5 showed the highest correlation two the sites JB-35 with factor 1 due to high water ionic richness in winter. Sites JB-41 and JB-55 showed an ionic concentration gradient. The other sampling points had less correlation with factor 1 due to both less ionic richness and total phosphorus values.

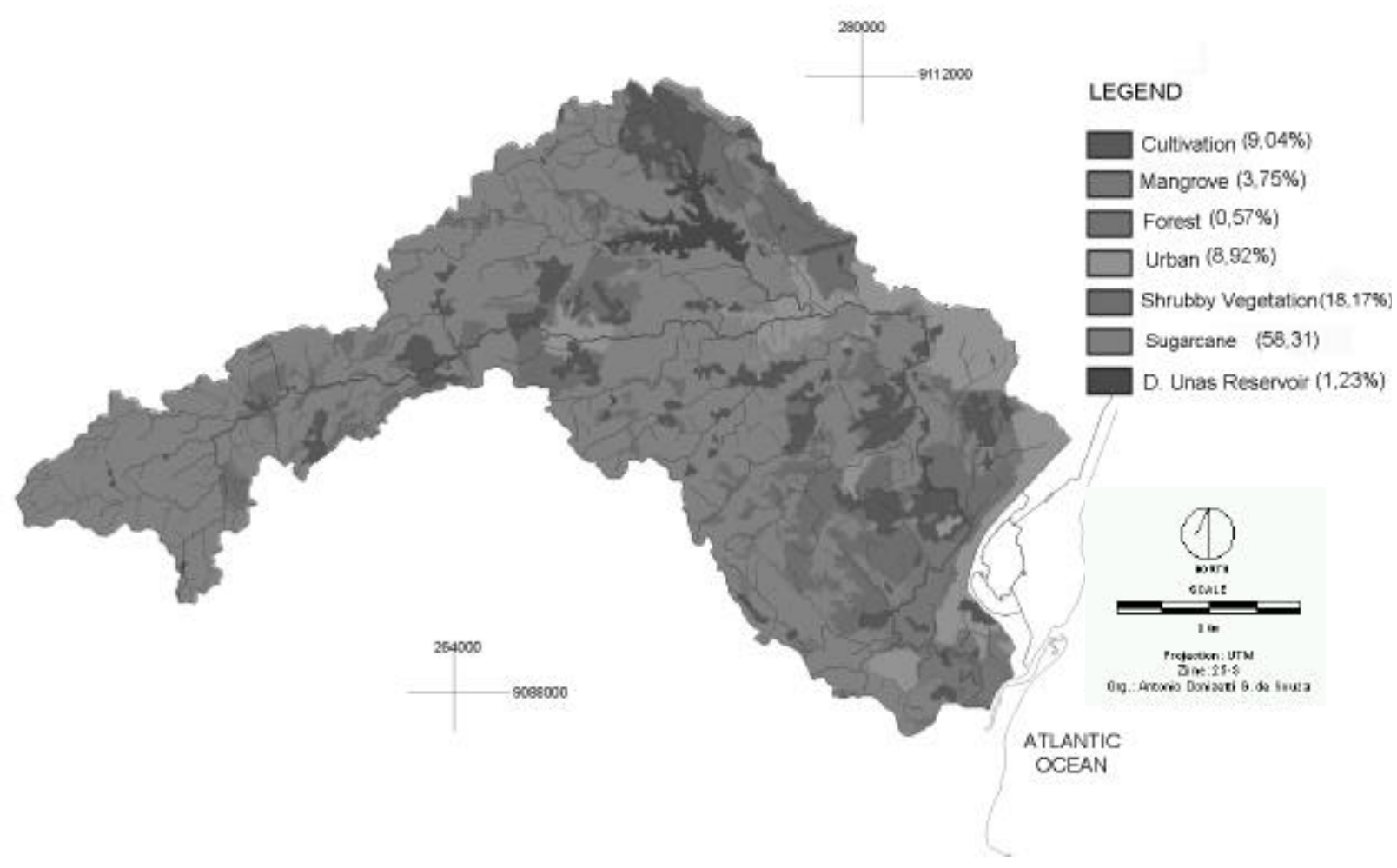

Figure 2 - Land use in Jaboatão watershed. 


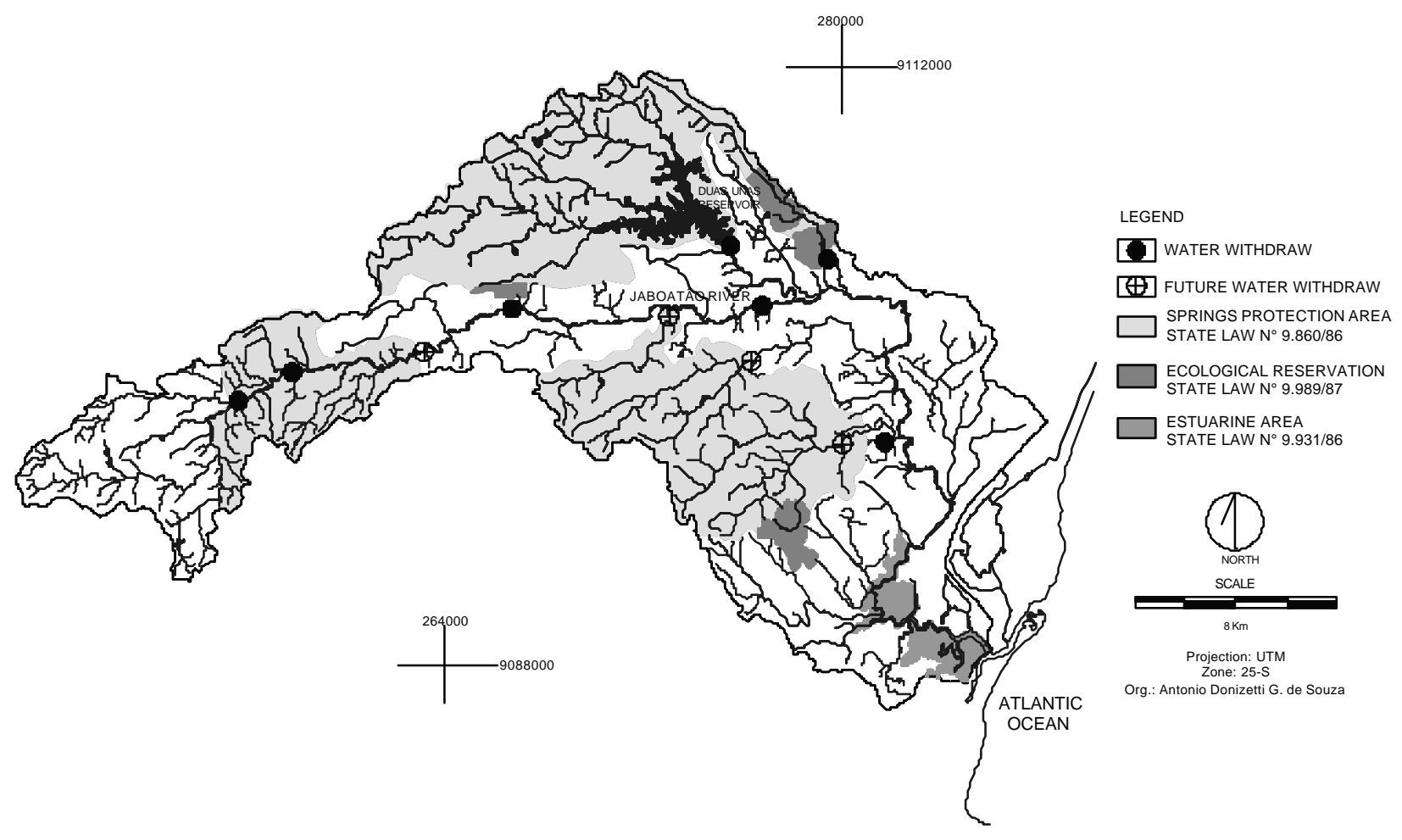

Figure 3 - Legal protection areas and water withdrawals in Jaboatão watershed.
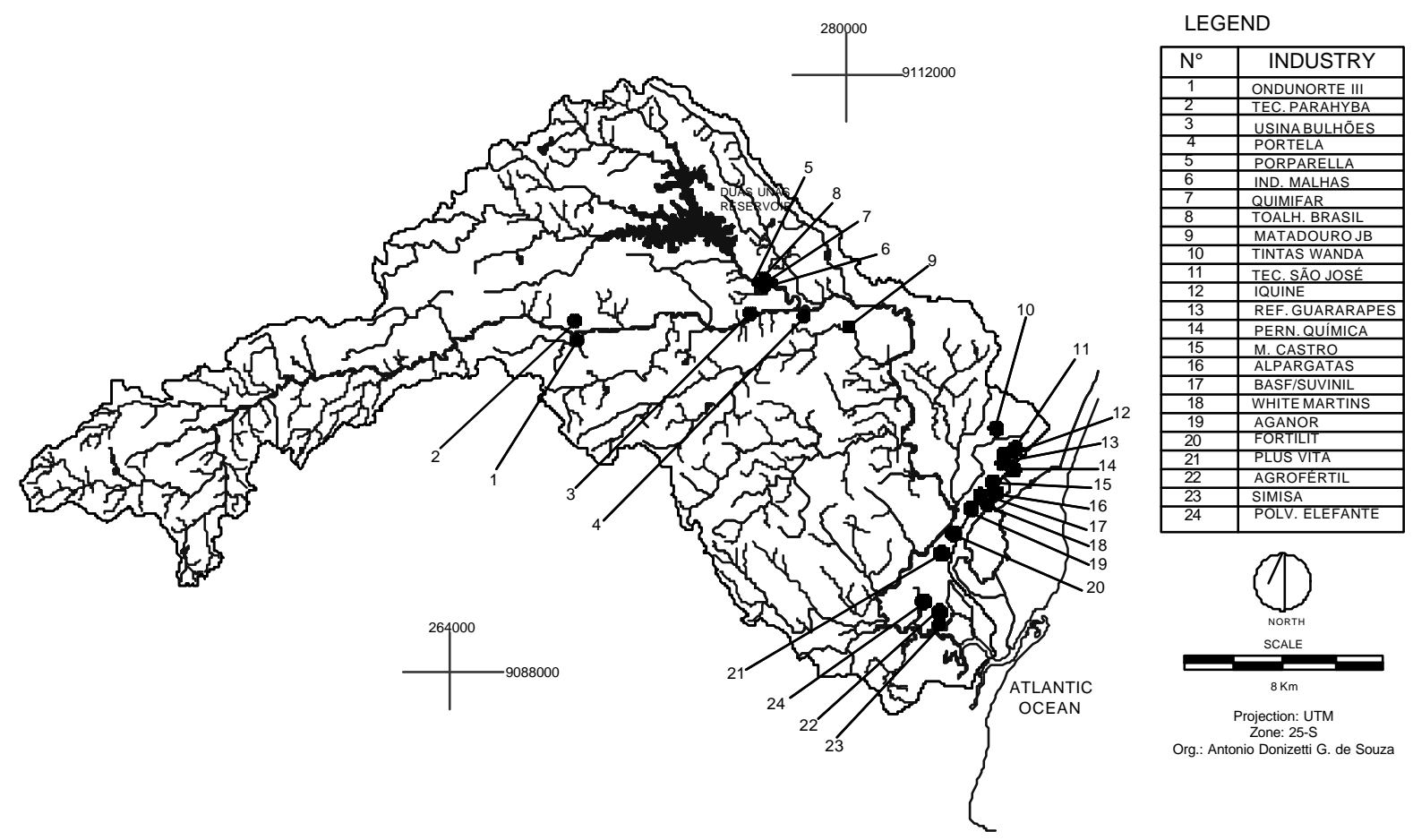

Figure 4 - Industrial sources of pollution in the Jaboatão watershed. 
In the summer, factor 1 explained $50.78 \%$ of the variance and contributed highly to: conductivity, chlorine, dissolved oxygen, and total solids. Factor 2 explained $25.63 \%$ of the variance and included $\mathrm{pH}$, alkalinity (positive correlation) temperature, and nitrate (negative correlation). The distribution of factors along the sites showed that station JB-75 was highly correlated with factor 1 . All other sites showed little influence of this factor due its correlation with oxygen (0.98). For factor 2 , sites JB-20 and JB-22 were most correlated by having the highest nitrate and temperature values. The higher homogeneity registered for the summer period showed water quality decline in most variables analyzed, specially with reference to oxygen, nitrate, total phosphorus, in addition to maintenance of fecal contamination levels.

The results of the comparison between water quality and classes determined by CONAMA resolution 20/86 showed that all sites should be included within class 3 and 4 limits, which are less restrictive (Fig. 6). In both studied periods (winter and summer), the critical variables were dissolved oxygen, total phosphorus, and fecal coliforms. These variables were also reported as critical in similar work by Gama et al. (1998) and Pereira and Lanna (1998) and indicated the anthropogenic impacts that occurred along the river.

For establishing water quality goals and classes in accordance with CONAMA resolution 20/86, the watershed was subdivided into representative areas with water use restrictions. These areas are represented in Figure 7 which shows water way segments in groups with the following characteristics:

\section{Group 1: Springs}

This group contained water bodies used as sources of urban supply and future withdrawals goals. This area included the rivers within the spring protection area and ecological reservations, besides others not listed but included anyway because of headwaters location. The classes to be proposed for this area were Special and Class 1.

Table 1 - Results of the variables registered at sampling sites of the Jaboatão watershed.

\begin{tabular}{|c|c|c|c|c|c|c|c|}
\hline Sites & Period & $\begin{array}{c}\text { Statistic } \\
\text { Descritive }\end{array}$ & $\begin{array}{c}\text { Temperature } \\
\left({ }^{\circ} \mathrm{C}\right)\end{array}$ & $\mathrm{pH}$ & $\begin{array}{c}\text { Alkalinity } \\
\text { (mg/L) }\end{array}$ & \begin{tabular}{|c|} 
Conductivity \\
(Us/cm)
\end{tabular} & $\begin{array}{c}\mathrm{Cl} \\
(\mathrm{mg} / \mathrm{L})\end{array}$ \\
\hline \multirow{3}{*}{ JB-10 } & \multirow[t]{2}{*}{ Winter } & Median & 27,25 & 6,65 & 54,50 & 181,25 & 25,40 \\
\hline & & Std. Dev. & 1,03 & 0,15 & 12,28 & 28,42 & 3,93 \\
\hline & \multirow[t]{2}{*}{ Summer } & Median & 28,75 & 7,00 & 66,30 & 261,00 & 37,60 \\
\hline \multirow{5}{*}{ JB-15 } & & Std. Dev. & 0,41 & 0,46 & 82,31 & 213,31 & 20,32 \\
\hline & \multirow[t]{2}{*}{ Winter } & Median & 27,50 & 6,55 & 41,50 & 150,90 & 23,25 \\
\hline & & Std. Dev. & 1,26 & 0,16 & 5,66 & 7,36 & 1,63 \\
\hline & \multirow[t]{2}{*}{ Summer } & Median & 29,25 & 6,85 & 61,95 & 205,50 & 29,75 \\
\hline & & Std. Dev. & 1,18 & 0,55 & 11,83 & 27,89 & 4,75 \\
\hline \multirow{4}{*}{ JB-20 } & \multirow[t]{2}{*}{ Winter } & Mediana & 28,00 & 6,85 & 48,25 & 176,05 & 25,95 \\
\hline & & Std. Dev. & 3,92 & 0,82 & 20,37 & 101,51 & 14,53 \\
\hline & \multirow[t]{2}{*}{ Summer } & Median & 31,75 & 6,45 & 85,90 & 422,50 & 53,55 \\
\hline & & Std. Dev. & 3,54 & 1,18 & 29,11 & 147,44 & 18,66 \\
\hline \multirow{4}{*}{ JB-22 } & \multirow[t]{2}{*}{ Winter } & Median & 27,75 & 6,75 & 61,25 & 216,50 & 35,30 \\
\hline & & Std. Dev. & 1,91 & 0,19 & 13,20 & 55,30 & 5,83 \\
\hline & \multirow[t]{2}{*}{ Summer } & Median & 31,50 & 6,45 & 96,00 & 433,50 & 61,70 \\
\hline & & Std. Dev. & 3,11 & 0,90 & 28,75 & 179,90 & 22,41 \\
\hline \multirow{3}{*}{ JB-35 } & \multirow[t]{2}{*}{ Winter } & Median & 27,00 & 7,20 & 190,00 & 549,00 & 73,30 \\
\hline & & Std. Dev. & 1,11 & 0,17 & 66,00 & 190,80 & 24,38 \\
\hline & \multirow[t]{2}{*}{ Summer } & Median & 29,00 & 7,75 & 414,85 & 1265,00 & 158,60 \\
\hline \multirow{5}{*}{ JB-41 } & & Std. Dev. & 1,30 & 0,56 & 150,12 & 425,98 & 59,68 \\
\hline & \multirow[t]{2}{*}{ Winter } & Median & 27,75 & 6,95 & 122,75 & 390,50 & 43,30 \\
\hline & & Std. Dev. & 2,27 & 0,25 & 63,13 & 99,57 & 15,09 \\
\hline & \multirow[t]{2}{*}{ Summer } & Median & 30,00 & 6,90 & 202,00 & 794,00 & 80,20 \\
\hline & & Std. Dev. & 2,00 & 0,48 & 113,19 & 249,53 & 25,83 \\
\hline \multirow{3}{*}{ JB-55 } & \multirow[t]{2}{*}{ Winter } & Median & 27,50 & 7,00 & 106,45 & 300,50 & 41,10 \\
\hline & & Std. Dev. & 0,90 & 0,07 & 29,18 & 73,64 & 13,64 \\
\hline & \multirow[t]{2}{*}{ Summer } & Median & 28,50 & 7,00 & 191,10 & 577,00 & 71,10 \\
\hline \multirow{5}{*}{ JB-75 } & & Std. Dev. & 0,53 & 0,44 & 81,70 & 258,99 & 31.52 \\
\hline & Winter & Median & 27,75 & 7,00 & 105,40 & 833,00 & 213,40 \\
\hline & \multirow{3}{*}{ Summer } & Std. Dev. & 1,61 & 0,11 & 29,71 & 9102,71 & 3729,37 \\
\hline & & Median & 27,75 & 7,20 & 125,00 & 20000,00 & 10692,00 \\
\hline & & Std. Dev. & 0,90 & 0,35 & 85,46 & 0,00 & 1846,79 \\
\hline
\end{tabular}




\begin{tabular}{|c|c|c|c|c|c|c|c|c|}
\hline Sites & Period & $\begin{array}{l}\text { Statistic } \\
\text { Descritive }\end{array}$ & $\begin{array}{c}\text { Dissolved } \\
\text { Oxygen } \\
\text { (mg/L) }\end{array}$ & (mg/L) & $\begin{array}{c}\text { Fecal } \\
\text { Coliforms } \\
(\mathrm{NMP} / 100 \mathrm{ml})\end{array}$ & $(\mu \mathrm{g} / \mathrm{L})$ & \begin{tabular}{|c} 
Total \\
Phosphoru \\
$\mathbf{s}$ \\
$(\mu \mathrm{q} / \mathrm{L})$
\end{tabular} & $\begin{array}{c}\text { Total } \\
\text { solids } \\
(\mathrm{mg} / \mathrm{L})\end{array}$ \\
\hline \multirow{4}{*}{ JB-10 } & Winter & Median & 1,20 & 8,75 & 160000,00 & 40,50 & 260,00 & 162,40 \\
\hline & & Std. Dev. & 0.72 & 5,33 & 68719.12 & 30.05 & 86.86 & 14.07 \\
\hline & Summer & Median & 0,90 & 31,80 & 160000,00 & 42,50 & 370,00 & 200,40 \\
\hline & & Std. Dev. & 1,02 & 27,57 & 0,00 & 20,12 & 634,74 & 140,79 \\
\hline \multirow{4}{*}{ JB-15 } & Winter & Median & 0,10 & 3,35 & 4650,00 & 18,00 & 170,00 & 136,80 \\
\hline & & Std. Dev. & 2,34 & 1,75 & 2683,75 & 74,38 & 53,81 & 9,84 \\
\hline & Summer & Median & 1,50 & 2,40 & 1700,00 & 20,00 & 135,00 & 178,15 \\
\hline & & Std. Dev. & 1,52 & 2,67 & 34986,66 & 5,56 & 48,10 & 18,78 \\
\hline \multirow{4}{*}{ JB-20 } & Winter & Mediana & 2,60 & 4,10 & 160000,00 & 87,00 & 280,00 & 152,00 \\
\hline & & Std. Dev. & 1,22 & 107,73 & 58889,73 & 110,57 & 47,58 & 220,90 \\
\hline & Summer & Median & 0,20 & 134,95 & 160000,00 & 320,00 & 2585,00 & 425,65 \\
\hline & & Std. Dev. & 2,79 & 589,21 & 63480,00 & 170,98 & 1394,73 & 280,89 \\
\hline \multirow{4}{*}{ JB-22 } & Winter & Median & 1,60 & 5,15 & 160000,00 & 109,00 & 350,00 & 178,20 \\
\hline & & Std. Dev. & 0,79 & 11,66 & 0,00 & 54,55 & 61,12 & 38,07 \\
\hline & Summer & Median & 0,00 & 89,00 & 160000,00 & 136,00 & 2095,00 & 414,05 \\
\hline & & Std. Dev. & 1,46 & 99,30 & 0,00 & 134,11 & 1133,82 & 231,01 \\
\hline \multirow{4}{*}{ JB-35 } & Winter & Median & 0,00 & 8,00 & 160000,00 & 26,00 & 980,00 & 376,00 \\
\hline & & Std. Dev. & 0,32 & 2,49 & 0,00 & 17,73 & 145,32 & 109,71 \\
\hline & Summer & Median & 0,00 & 23,00 & 160000,00 & 16,50 & 2435,00 & 828,25 \\
\hline & & Std. Dev. & 0,15 & 6,58 & 50000,00 & 5,87 & 1119,43 & 252,03 \\
\hline \multirow{4}{*}{ JB-41 } & Winter & Median & 0,00 & 34,00 & 160000,00 & 45,50 & 890,00 & 351,00 \\
\hline & & Std. Dev. & 0,00 & 21,80 & 0,00 & 28,61 & 312,51 & 128,43 \\
\hline & Summer & Median & 0,00 & 135,40 & 160000,00 & 29,00 & 1770,00 & 334,00 \\
\hline & & Std. Dev. & 0,64 & 64,71 & 52000,00 & 18,38 & 750,96 & 263,00 \\
\hline \multirow{3}{*}{ JB-55 } & Winter & Median & 0,00 & 4,35 & 26900,00 & 22,00 & 480,00 & 275,40 \\
\hline & & Std. Dev. & 0,61 & 6,41 & 63978,28 & 29,04 & 174,42 & 68,94 \\
\hline & Summer & Median & 0,00 & 9,25 & 10500,00 & 31,00 & 1305,0 & 446,60 \\
\hline \multirow{5}{*}{ JB-75 } & & Std. Dev. & 0,44 & 12,99 & 56418.39 & 85,33 & 4957 & 16549 \\
\hline & Winter & Median & 0,60 & 3,95 & 40000,00 & 23,50 & 460,00 & 525,25 \\
\hline & & Std. Dev. & 0,67 & 1,74 & 24914,86 & 13,98 & 245,31 & 7455,35 \\
\hline & Summer & Median & 3,80 & 2,60 & 31500,00 & 150,00 & 120,00 & 21435,00 \\
\hline & & Std. Dev. & 0,59 & 1,17 & 19828,96 & 100,80 & 146,78 & 4558,38 \\
\hline
\end{tabular}

Group 2: Estuary

The water bodies of this group are located in the lower portion of the watershed, within the protected estuarine area. They were part of mangrove areas and require, like the area group 1, special protection measures. Studies should be made to determine the zone of influence of the tide. In their absence, it appeared that this region should be included in classes 7 and 8 (brackish waters)

Group 3: Urban

This group included water bodies in urban areas within the watershed. These areas required recovery measures and control and organization of urban expansion, including collection and treatment of domestic, industrial effluents, and solid residues. They were obviously critical reaches where the class 2 standard should be established as the goal.

\section{Group 4: Urban/Industry}

These areas presented rivers crossing highly and industrialized urban zones in expansion in the watershed and areas not included in group 3. In these areas environmental control and inspection were indispensable in improving and recovering water quality. The region was critical and class 2 should be established as the goal for tributaries with class 3 as in the main course of the Jaboatão river. 
Table 2 - Factor analysis. Factor loading of variables measured for winter and summer periods.

\begin{tabular}{l|c|c|c|c}
\hline \multirow{2}{*}{ Variables } & \multicolumn{2}{c}{ Winter } & \multicolumn{2}{c}{ Summer } \\
\cline { 2 - 5 } & Factor $\mathbf{F}$ & Factor 2 & Factor 1 & Factor 2 \\
\hline Temperature & $-0,39$ & $-0,06$ & $-0,59$ & $\mathbf{0 , 7 6}$ \\
pH & $\mathbf{0 , 8 3}$ & $-0,30$ & 0,13 & $\mathbf{0 , 9 1}$ \\
Alkalinity & $\mathbf{0 , 9 1}$ & $-0,30$ & $-0,35$ & 0,71 \\
Conductivity & $\mathbf{0 , 8 6}$ & 0,18 & $\mathbf{0 , 9 1}$ & 0,03 \\
Chlorine & 0,64 & 0,39 & $\mathbf{0 , 9 2}$ & 0,01 \\
Dissolved Oxygen & $-0,69$ & $-0,27$ & $\mathbf{0 , 9 8}$ & $-0,66$ \\
BOD & 0,30 & $-0,61$ & $-0,53$ & $-0,24$ \\
Fecal Coliforms & $-0,12$ & $\mathbf{- 0 , 9 2}$ & $-0,63$ & $\mathbf{- 0 , 8 5}$ \\
Nitrate & $-0,60$ & $-0,57$ & 0,18 & $-0,21$ \\
Total Phosphorus & $\mathbf{0 , 8 1}$ & $-0,55$ & $-0,75$ & 0,03 \\
Total Solids & $\mathbf{0 , 9 1}$ & 0,09 & $\mathbf{0 , 9 1}$ & 2,82 \\
Eigenvalues & 5,26 & 2,28 & 5,58 & 25,63 \\
\hline Total Variance & 47,83 & 20,78 & 50,78 & \\
\hline
\end{tabular}
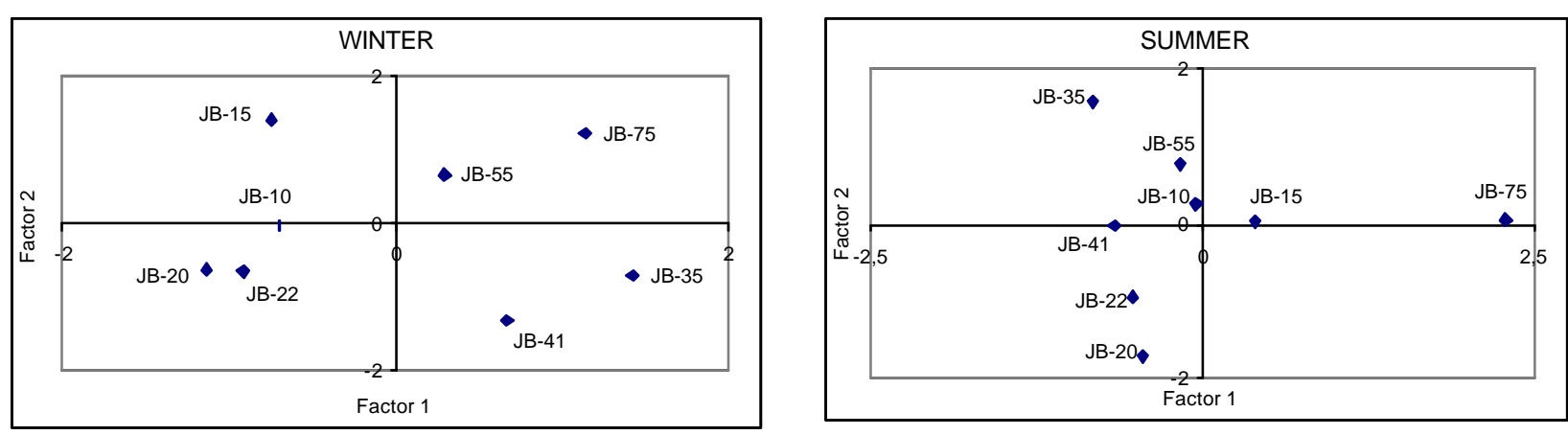

Figure 5 - Distribution of sampling sites (factor scores) according to factors 1 and 2.

The groups of uses and water quality classes suggested above could serve as a basic framework lending support to more detailed studies on the watershed. This study showed a condition of environmental degradation as attested by several water quality variables analyzed in the Jaboatão watershed. In the stations representing urbanized areas, JB-10, JB-20, JB-22, JB-35, and JB-41, the worst water quality conditions were found, specially in the summer period, resulting from industrial and domestic effluents. The critical variables were dissolved oxygen, fecal coliformes, and total phosphorus, which placed the area within class 3 and 4 according CONAMA resolution 20/86. Water use regulation was proposed as an useful tool in beginning discussion of water quality goals according classification system proposed by the CONAMA resolution.

The approach presented in this study could be used as a subsidy by the watershed protection committee and public agencies responsible for establishing guidelines and effective measures for watershed protection and recovery. 

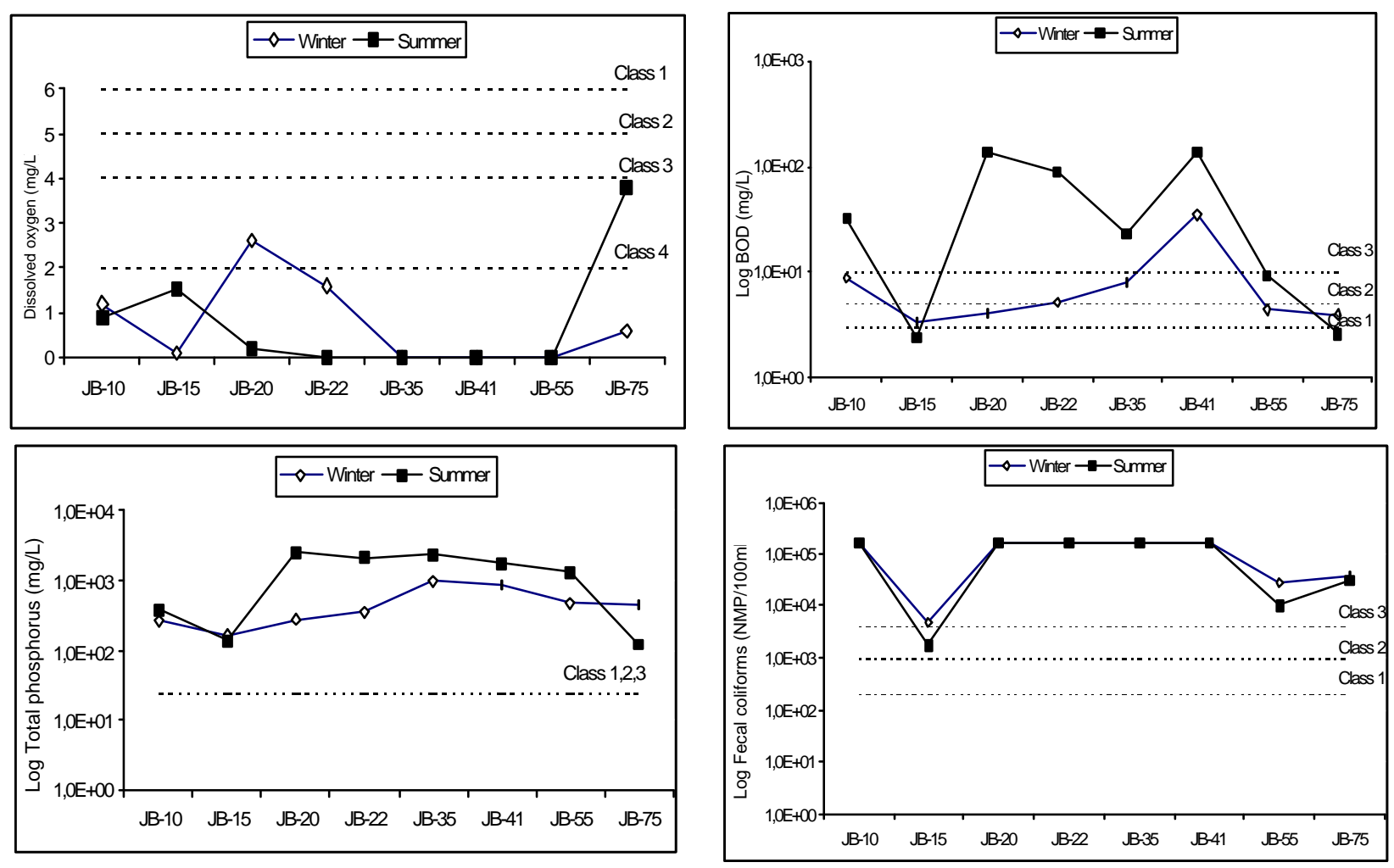

Figure 6 - Comparison of water quality registered and classes of CONAMA resolution 20/86.

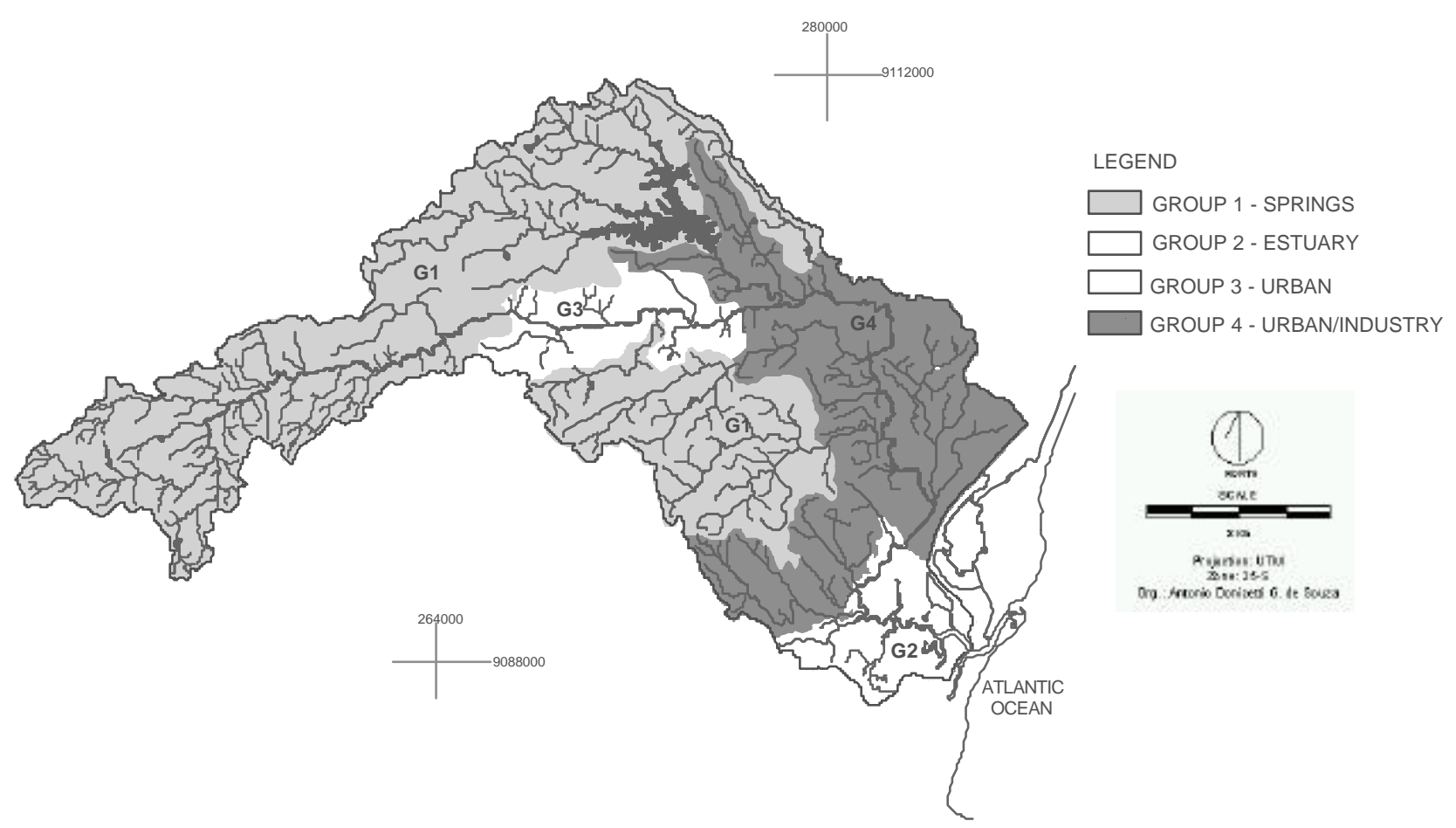

Figure 7 - Groups of the water restricted uses propose for Jaboatão watershed. 


\section{ACKNOWLEDGEMENTS}

The authors express their thanks to Companhia Pernambucana do Meio Ambiente (CPRH) for the institutional and operational support in this study and to Conselho Nacional de Desenvolvimento Científico e Tecnológico (CNPq).

\section{RESUMO}

O presente estudo teve como objetivos avaliar as influências antrópicas sobre a qualidade da água na bacia do rio Jaboatão (Pernambuco, Brasil) e fornecer subsídios ao enquadramento dos corpos d'água em classes de usos. Foram realizadas coletas mensais de água durante o período de março/98 a fevereiro/99 em oito estações de amostragem. As seguintes variáveis foram medidas: temperatura, $\mathrm{pH}$, condutividade, alcalinidade, $\mathrm{Cl}$, oxigênio dissolvido, DBO, coliformes fecais, nitrato, fósforo total e sólidos totais. As variáveis oxigênio dissolvido, coliformes fecais e fósforo total, foram as mais críticas para o enquadramento. Foram delimitados grupos de usos da água na bacia e sugeridas classes de qualidade para cada grupo, fornecendo, desta maneira, elementos para auxiliar o gerenciamento da qualidade da água

\section{REFERENCES}

Acquaplan (1990), Estudo de impacto ambiental da barragem do rio Jaboatão, Recife, ACQUAPLAN.

Apha - Awwa- Wpcf (1995), Standard methods for the examination of water and wastewater, 19th ed. American Public Health Association, American Water Works Association, Water Polution Control Federation, Washington, DC, USA.

Barth, F. T. (1999), Aspectos institucionais do gerenciamento de recursos hídricos. In: Rebouças, A. Braga, C. B. and Tundisi, J. G. (eds.). Águas doces do Brasil. São Paulo : Escrituras Editora. pp. 565-599.

BRASIL (1986), CONAMA - Conselho Nacional do Meio Ambiente, Resolução $n^{\circ} 20$ de 18/06/1986. Dispõe sobre a classificação das águas doces, salobras e salinas do território nacional.

BRASIL (1997), Lei $n^{\circ} 9433$ de 08/01/1997. Institui a Política Nacional de Recursos Hídricos, cria o Sistema Nacional de Gerenciamento de Recursos Hídricos.

CPRH (1995), Relatório Anual de Atividades. Recife : CPRH.
Dimitrova, I.; Kosturkov, J. and Vatralova, A. (1998), Industrial surface water pollution in the region of Devnya, Bulgaria. Water Science and Technology, 37, 45-53.

Evison, L. M. (1998), Comparative studies on the survival of indicator organisms and pathogens in fresh and sea water. Water Science and Technology, 20, 309-315.

Fidem (1987a), Proteção dos mananciais. Série Desenvolvimento Urbano e Meio Ambiente. Fidem, Recife.

Fidem (1987b), Reservas Ecológicas .Série Desenvolvimento Urbano e Meio Ambiente. Fidem, Recife.

Fidem (1987c), Proteção das Áreas Estuarinas. Série Desenvolvimento Urbano e Meio Ambiente. Fidem, Recife.

Fidem (1995), Mapa da cobertura vegetal da Região Metropolitana do Recife, escala 1:100.000. Fidem, Recife.

Gama, A. M. C. F., Cavalcanti, D. J. and Farias, V. (1998), O enquadramento e a classificação da qualidade atual dos rios da bacia do rio Pirapama. Simpósio Internacional sobre gestão de recursos hídricos, 5-8 outubro, Gramado, Brasil.

Guaglianoni, L. G. (1998), A remoção de compostos organoclorados tetraclorocatecol e tetracloroguaniacol contidos em efluentes da industria de papel e celulose. Tese (Doutorado), Universidade de São Paulo, São Carlos, Brasil.

Hanes, N. B. and Fragala, R. (1967), Effect of seawater concentration on survival of indicator bacteria. Journal of the Water Pollution Control Federation, 39, 97-104.

Leitão, R.C. (1991), Avaliação do processo eletrolítico para remoção de cor devida lignina. Dissertação (Mestrado), Universidade de São Paulo, São Carlos, Brasil.

Maier, M. H. (1977), Estudo da variação sazonal das condições físicas e químicas ao longo de um trecho do rio Mogi-Guaçu - Cachoeiras de Emas, Estado de São Paulo. Dissertação (Mestrado), Universidade Federal de São Carlos, São Carlos, Brasil.

Mallin, M. A.; Williams, K. E.; Esham, E. C. and Lowe, R. P. (2000), Effect of human development on bacteriological water quality in coastal watersheds. Ecological Applications, 10, 1047-1056.

Pegram, G. C.; Quibell, G. and Hinsch, M. (1999), The nonpoint source impact of per-urban settlements in South Africa: implications for their management. Water Science and Technology, 39, 283-290.

Pereira, J. S. and Lanna, A. E. (1998), O enquadramento dos corpos d'água em classe de uso como um instrumento de gestão e a necessidade de revisão da resolução CONAMA 20/86. Simpósio Internacional sobre gestão de recursos hídricos, 5-8 outubro, Gramado, Brasil. 
Peters, N. E. and Meybeck, M. (2000), Water quality degradation effects on freshwater availability: impacts to human activities. Water International, 25, 214-221.

Prat, N. and Munné, A. (2000), Water use and quality and stream flow in a Mediterranean stream. Water Resource, 34, 3876-3881.

Seager, J. (1993), Statutory water quality objectives and river water quality. Journal of the institution of water and environmental management, 7, 556-563.

Received: January 21, 2002; Revised: September 19, 2002;

Accepted: March 21, 2003. 